\title{
Security Systems in Francophone and Anglophone Africa
}

\author{
Niagalé Bagayoko
}

\begin{abstract}
This article analyses the commonalities and differences between African anglophone and francophone security systems in the context of security sector reform. Although each country has a distinct political history and tradition, similarities in the security apparatus, rooted in its inheritance from the colonial and post-colonial periods, can be found in both sets of countries. Identifying better ways to harmonise the SSR programmes being implemented all over the African continent requires a deep understanding of the similarities and differences which exist between African countries that belong to different linguistic areas and inherited from colonial rule. Security governance has been improving in an important number of anglophone countries over the last few years, while Francophone African countries are usually presented as not having experienced any significant transformation in security governance. Influencing factors of relative success or failure include institutional patterns; decision-making structures; type of defence and police forces; and training capacities.
\end{abstract}

\section{Introduction: can SSR fit all African environments?}

In recent years, anglophone countries have arguably been more open to changes towards increased accountability of their security forces (ministries of defence relatively independent from the armed forces; parliamentarian oversight; accountability to audit bodies, ombudsmen, human rights commissions, etc.) than their francophone equivalents. Partly this may reflect variations in their respective democratic transition processes. But another factor has been the active promotion of security sector reform (SSR) itself in countries like Sierra Leone, Ghana, etc., together with some cross-fertilisation among anglophone countries, as well as the demonstration effects of the South African model. The situation is of course far from ideal: in many countries, security ministries still tend to be weak and badly resourced; the mechanisms of 'horizontal' accountability - to audit bodies, ombudsmen, human rights commissions, etc. - are weak in essence, and military forces have fared better than the police forces. But it cannot be denied that security governance has been improving in an important number of anglophone countries over the last few years.
Francophone African countries are usually presented as not having experienced any significant transformation in security governance. The recent seizure of power by the military - or with their complicity - in several states is seen as dramatic evidence of the total lack of improvement in security governance. However, the situation is much more complex. It is also important to be aware that an important number of countries, including non-democratic ones, have tiptoed into a process of reform. Most of the time, those reform processes have been undertaken and framed without the SSR label. But they are in fact resulting in more professional and accountable security forces, which is the overarching purpose of the SSR approach.

Identifying better ways to harmonise the SSR programmes being implemented all over the African continent requires a deep understanding of the similarities and differences which exist between African countries that belong to different linguistic areas and inherited from colonial rule. The issue at stake is neither to provide a performance rating of francophone and anglophone security apparatus nor to define performance benchmarks against which security apparatuses should be systematically assessed.

IDS Bulletin Volume 43 Number 4 July 2012 (c) 2012 The Author. IDS Bulletin ( 2012 Institute of Development Studies Published by Blackwell Publishing Ltd, 9600 Garsington Road, Oxford OX4 2DQ, UK and 350 Main Street, Malden, MA 02148, USA 
This article aims to provide a better understanding of the institutional, organisational, bureaucratic and legal security arrangements operating in Francophone and Anglophone African countries, to highlight their commonalities and differences and to provide an overview of the actors, structures, and how security systems function. Former French territories (Benin, Burkina Faso, Cameroon, Chad, Congo, Cote d'Ivoire, Central Africa, Gabon, Guinea, Mali, Niger, Senegal and Togo) ${ }^{1}$ and former British and American colonies (Botswana, Eritrea, Ethiopia, Gambia, Ghana, Kenya, Lesotho, Liberia, Malawi, Mauritius, Namibia, Nigeria, Sierra Leone, Somalia, South Africa, Sudan, Swaziland, Tanzania, Uganda, Zambia and Zimbabwe) are reviewed in this article.

\section{Institutional patterns}

All francophone countries have centralised presidential systems, in which security bureaucracies report directly or indirectly to the President. Although anglophone countries initially had an inherited tradition of parliamentary government, in reality presidential control has also prevailed in all of them. In the two sets of countries, the prominence of the executive branch has downsized the role of the parliaments, although this is still formally recognised by the constitutions.

\subsection{The central role of the President}

In Francophone Africa, the legacy of colonialism and then the adoption of constitutions inspired by - if not carbon-copied from - the French Fifth Republic Constitution have resulted in the concentration of power in the executive branch. A constant feature of most francophone Constitutions is the President of the Republic presiding over all security apparatuses, whilst the government - mostly through the ministries of defence, interior/internal security and justice - is responsible for implementing security policies. The President also has the power to appoint civilian and military positions (for instance the Chief of General Staff of the armed forces, as well as other heads of the civilian and military administration). The President can also hold 'exceptional powers' and has the power to declare a state of emergency, though this can only be after consultation with his Council of Ministers. Furthermore it is important to note that most of the Francophone African constitutions have also integrated provisions inspired by the American Constitution: they appoint the President as the 'supreme commander in chief of the armed forces', the adjective 'supreme' being directly taken from the American Constitution.

Initially, institutional arrangements in most anglophone countries reflected the distinctively British heritage, for example parliamentary government, common law, sharp separation in principle between external defence and internal policing, hence between military and police, etc. However, most anglophone countries have shifted toward presidential governance, not least in relation to the security sector - hence tending to converge with French-speaking countries. Currently, nearly all the constitutions in former British colonies (with the exception of Ethiopia, Lesotho and Swaziland), provide for the presidential system of government, as opposed to the Westminster parliamentary system inherited at independence. Furthermore, in Anglophone Africa, security governance influences stem from models other than the United Kingdom institutional tradition - either from widespread links with other Commonwealth countries or from the USA - for example, in Nigeria where the federal constitution, presidential government, the bicameral legislature and its select committees etc., reflect the US influence even more than the British. The US influence is also paramount in Liberia. As in Francophone Africa, it is worth noting that constitutional provisions inspired by the US Presidentialist Constitution have been integrated in a number of other anglophone countries, especially the provision entitling the President of the Republic as Supreme Chief of the armed forces. The constitutions stipulate that the President has ultimate powers to determine the operational use of all security forces. The President also appoints the ministers in charge of the ministries of defence, home/internal affairs and intelligence. The President also has the executive power to appoint the operational commanders of the security forces such as the Defence Chief of Staff as well as the Inspector General (in some countries called commissioner) of Police, and the Inspector General of Intelligence.

\subsection{Role of the parliaments}

In both Anglophone and Francophone Africa, parliamentary oversight of the security services is provided for in most constitutions. Since the 1990s, the francophone constitutions have established a 
system of separation and collaboration between the executive and the legislative branches. Most of them state that the parliament is in charge of declaring war and of ratifying peace agreements. Moreover, as in France, the constitutions of Francophone African states recognise that 'the fundamental principles of the general organisation of the national defence' result from the legal domain, which means that their defence policies are passed into law by the legislature, though only after being reviewed by the appropriate committee. Furthermore, the national assembly may call on the security forces to defend national territory, or to approve or amend any act relating to new alliances. Most of the time, it has to approve any engagement of its armed forces abroad. In countries such as Benin and Niger, the parliament is entitled to adopt bills that ratify any international alliance: this includes military assistance agreements. Generally, the national assembly has the power to monitor the actions of the government through consideration of the budget (including a facility to approve the funds that are to be allocated to various security structures, to revise it downwards or upwards or to redirect budget allocations toward other areas); questions to the government; and parliamentary standing committees (on national defence, security, justice and civil protection). Like all other standing committees, these committees have a duty to monitor the actions of the government; they may hold audiences with ministers, and call before them anyone who needs to be consulted. The committees receive draft bills from the government but, in some countries such as Benin and Mali, they may also propose laws on security issues. These committees are, however, mainly in charge of carrying out surveys and drafting amendments. They are not investigative bodies, nor are they units that provide direct control of the activities of the security sector, even if they are allowed to call on external expertise.

In anglophone countries under presidential constitutions, the parliament is empowered to make laws to regulate the President's constitutional powers as Commander-in-Chief of the security services. As in Francophone Africa, parliaments are empowered to form select committees on particular security services for the purpose of oversight. Apart from Lesotho and Malawi, all national parliaments in Anglophone Africa have select committees responsible for monitoring the security sector. In larger parliaments, like Nigeria's and South Africa's, the parliament has separate committees on defence (in addition to defence, the Senate in Nigeria has a committee for the army, air force and navy), police and intelligence. In smaller parliaments, such as that of Zambia and Ghana, defence and the interior are combined under one committee. There are also committees on appropriation and public accounts, which are meant to debate, approve and review defence, internal security and intelligence budgets. In addition, the committees have powers to conduct investigations into security matters, and to review the management of security by the executive branch as the need arises. This includes the power to summon the President, ministers or heads of the security services to the parliament to defend their actions.

The role of parliaments, as acknowledged by the constitutions, is therefore very similar in Francophone and Anglophone Africa. However, in the two sets of countries, the constitutional provisions related to parliamentarian oversight have more than often been ignored in practice.

\section{Decision-making structures}

An important difference between Anglophone and Francophone Africa is the existence of collegial organs meant to be fully associated in the decision-making process.

\subsection{NSC and High Councils on National Defence}

In almost all anglophone countries, the appointments and decisions are supposedly made on the advice of collegial organs which are established to advise the President on policy matters relating to security and consequently have an important role in the policy decisionmaking process. The Cabinet is the highest decision-making organ of government, and this includes national security policy. Moreover, in the last ten years, structures and policy review processes, such as Defence Reviews and/or National Security Reviews and White Papers, have been introduced and interagency decisionmaking structures have been set up. At the top of all national security organs is the National Security Council (NSC), which coordinates all security policy and advises the President on national security matters. The NSC, which is under the direct control of the presidency, is managed by a National Security Adviser (as in Nigeria) or a National Security Coordinator (as 
in Ghana and Sierra Leone). NSG meetings are presided over by the President and are made up of the Ministers of Foreign Affairs, Defence, Interior, and Finance, and other ministers such as the President determines. Other members of the NSG are the Chief of Defence Staff (or alternatively Force Commander), the Inspector General of Police and the directors of the various intelligence agencies. The influence of those NSGs of course varies from case to case.

Two other important national organs that can be found in many anglophone countries are the Defence Council and the Police Council. Known as the Armed Forces Council in some countries (for example in Ghana and the Gambia), the Defence Council is principally responsible for advising the President on defence policy and acts as a mechanism for executive control and supervision of the defence forces. It is usually chaired by the President and includes the Ministers of Foreign Defence, Foreign Affairs, and the Interior, the Chief of Defence Staff, as well as the service chiefs; the President may appoint other members. The Defence Council is only advisory and, in practice, Presidents do make defence-related decisions without recourse to it, particularly in countries with weaker democratic credentials. The Police Council is principally responsible for advising the President on internal public security and safety policy. In some countries the Police Council is chaired by the Vice-President (as in Ghana), and others, the President (Nigeria), while other members include the Minister of the Interior, the Inspector General of Police/Police Commissioner and the Attorney General.

In Francophone Africa, beyond the Council of Ministers (under the authority of the Prime Minister) which is in theory the first level of coordination, there are no integrated processes combining external defence, internal security, policing, etc. within a single policy frame, coordinated at the national level that can be seen as comparable to the NSG. In most countries however, the constitution sets up High Councils on National Defence which are in fact rather similar to the Defence Councils that can be found in Anglophone Africa, including with regard to their lack of real influence. The High Councils of Defence, once again modelled on their French counterparts, are chaired by the President of the Republic and bring together all ministers involved in security and defence matters. Even if supposedly meant to think about strategic orientations of the defence and security policy, these structures are only focused on defence and military policy. These Councils on National Defence only have an advisory role. They are on no account a decision-making body: most of the time, these structures are a hollow and empty shell. Most francophone countries do not have any coordination structure to deal with internal security matters. An interesting exception is Burkina Faso where a coordinating unit for internal security forces was implemented in 2001 (police, gendarmerie and fire brigade).

\subsection{Organisation of the Defence Ministry}

An important difference between Francophone and Anglophone Africa is related to the division within the ministries of defence themselves. In almost all anglophone countries, the Ministry of Defence (or Department of Defence) is organised along British lines and Western tradition. The operational commands of the forces usually work together with a civilian bureaucracy of respective ministries. At the head of the ministry is a civilian minister appointed by the President. The Ministry of Defence, which is responsible for the development and implementation of national defence policy, is made up of a defence secretariat (defence bureaucracy) and a defence headquarters, which are headed by the (Permanent) Secretary/Minister of Defence and the Chief of Defence Staff (known as Force Commander in some countries), respectively. The Secretary is the chief accounting officer for the ministry and advises the Minister of Defence on policy matters. The Chief of Defence Staff is responsible for the operational command of the armed forces and advises the minister on operational matters related to national defence. The ministry is therefore a crucial mechanism for civil control and executive supervision of the armed forces.

Such a clear distinction between civil and military functions is far from widespread in francophone ministries of defence: on the contrary, MOD are most of the time administered by the military.

\section{Types of defence forces}

A number of defence forces in Francophone Africa (such as Presidential Guards and National Guards) have no real counterpart in Anglophone Africa. Furthermore, francophone defence forces 
are often officially endowed with development missions, contrary to anglophone armed forces.

\subsection{The Republican/Presidential Guards}

Presidential Guards are common in Francophone African countries. Officially, the mission of the Presidential Guard is to protect the Head of State when he travels abroad or within the country, and the presidential residences. The Presidential Guards are usually drawn from the rank of the military (officers and non-commissioned officers) and the gendarmerie. However, the Presidential Guards - called the republican guard in some Francophone African countries which references the French Republican Guard - are often configured as praetorian bodies. These forces are usually appointed on the basis of their loyalty towards the President and recruited according to ethnic criteria. The Presidential Guard is the core security body in francophone non-democratic countries. Even if they are formally integrated into the armed forces' chain of command, these Presidential Guards are not accountable to the Chief of Staff or to the Ministry of Defence: they are accountable to virtually no one, except to the President.

Presidential Guards can also be found in less authoritarian states. Even if their missions are less challenging, they enjoy special status. The Presidential Guards are one of the major symptoms of the system of competing security agencies and parallel chains of command which characterise the military in Francophone Africa. The Presidential/Republican Guards are generally better equipped than the other armed forces and they also enjoy virtual immunity for the crimes and abuses they commit. In some countries, the Presidential Guards have been reformed however (in Niger for instance).

In the past, a number of anglophone countries sadly experienced Presidential Guards. In Ghana, Nkrumah established the President's Own Guard Regiment in the 1960s. Jerry Rawlings also had his own special protection units. Many other anglophone countries have established similar units, though these have varied from country to country and period to period. Today, formal Presidential/Republican Guards are rare in Anglophone African countries. However, in practice, a few countries have specialised brigades within the army, known as the Brigade of Guards, which provides protection for the President. Arguably francophone countries differ mainly in that Presidential Guards have been a more uniform and more institutionalised force.

\subsection{The National Guards}

In Mali and Mauritania, the National Guard carries out important duties both military and civilian in essence. It contributes to maintaining order and public safety as well as to the general policing of territorial communities. It is entrusted with providing security to political and administrative institutions and is also involved in the prison services. What is specific about the National Guard is that it has the ability to grow into a formidable fighting force, capable of serving alongside the army. The National Guard is managed by the Minister of Defence but in terms of operations is under the authority of the Minister of the Interior. Generally, a Chief of General Staff heads, coordinates and controls the activities and duties of the division commanders and the heads of units (who command the territorial units in the provinces). The National Guard is present all over the national territory and works essentially to the benefit of the administration and the population. It is a highly decentralised force and it traces the administrative division of the country. National Guards are particularly worth considering because they were reformed during the 1990s in order to integrate members of former rebel movements from the Sahelian region.

Deploying National Guards is not a common practice in Anglophone Africa. Nigeria under military rule experimented with the idea of a National Guard in the late 1980s and early 1990s, but this was quickly abandoned.

\subsection{Development missions for the armed forces}

Traditionally most francophone countries have a role envisioned for their armies in both economic development and in education. In a number of countries, the constitutions state that the armed forces may participate in the economic, social and cultural development of the country. Even if those missions are not explicitly mentioned in the constitutions themselves, missions that involve the military in development or humanitarian projects are often considered as a possible (and legitimate) role for the armed forces. Because of its resources, the military is often seen as the only competent organisation 
able to perform a wide range of developmental tasks in more remote areas. The use of the armed forces is also seen as a way of creating a combination of interests between the population and the military. The armies of Mali, Senegal and Benin have been particularly active in this area (training the public in basic hygiene and sanitation; implementing inoculation and vaccination campaigns; building or repairing schools and/or roads; and providing air transport facilities to remote areas).

In anglophone countries, only specific units of the armed forces, namely the engineering corps (and in some cases the health service), are involved in development missions.

\section{Police forces}

It is worth noting that both in Francophone and Anglophone African countries, the operational capabilities of the police forces have been deliberately undermined by political rulers. In most African countries, police forces have been treated as inferior to the military both in status and resources. Under-resourcing has resulted in the inability of the police to grapple with public insecurities arising from high crime rates and serious internal security threats (Anderson and Killingray 1992). The consequent loss of public confidence in the police has led to the delegitimisation of the public police and recourse to the military (resulting in a blurring of internal and external security functions) and/or to privatised sources of security and protection such as corporate security companies and vigilantes.

Consequently, reforming and enhancing the operational capabilities of the police forces are top priorities in both Francophone and Anglophone countries. However, it is paramount to address the reforms taking into account the very different organisational frameworks of policing in Francophone and Anglophone Africa. Indeed, one of the defining differences between francophone and anglophone states rests in large part on the kind of security forces that are responsible for the maintenance of internal order.

\subsection{Police forces in Francophone Africa}

In most Francophone African countries that used to be under French colonial rule, the policing system is modelled on the French system. Two different services are nationally involved in the protection of internal order: the police forces on the one hand and the gendarmerie forces on the other. The relevance of the latter has been questioned over the last few years. In addition, in some countries, municipal police forces operate alongside these two forces and are under the mayor's supervision.

\subsubsection{Organisational, territorial and functional divisions between police forces at the national level}

To understand the way in which policing functions in Francophone African countries, it is necessary to make a three-fold distinction: organisational, territorial and functional.

The first division between the police forces and the gendarmerie forces is organic/organisational in essence. The National Police, headed by the General Directorate of the National Police (Direction Generale de la Police Nationale - DGPN), come under the responsibility of the minister in charge of security (in some cases also called the Minister of the Interior). In most cases, the General Directorate of National Police is divided into the following departments (Kurian 2006): the department of public security, in charge of maintaining public order and controlling common offences (assaults, rape, theft, fraud, mugging, etc.); the criminal investigation department (judiciary police), which investigates and prosecutes major and organised crime; the territorial surveillance department, which issues permission to enter or exit the national territory (counterpart of the so-called 'police aux frontieres' in France); and the intelligence department, responsible for administrative inquiries and individual surveillance. Each department is divided into several more general departments, regional departments, provincial departments, country desks, and services. In the various regions, departments are placed under the administrative authority of the regional governor, and under the technical authority of the director general. This dual layer of hierarchical and technical authority enables regional governors to carry out their roles as both regional civil services, and chiefs of security in their area of expertise.

On the other hand, the gendarmerie can be defined as a civilian police force with military status. The national gendarmerie is part of the military forces, and comes under the jurisdiction of a general directorate of the Ministry of Defence, which is responsible for budget, recruitment, education, training, equipment, administration and logistics 
of the gendarmerie forces. However, in operational matters, the gendarmerie has to respond to the agency that requires and asks for its services, namely the Ministry of Interior on the one hand and the Ministry of Justice on the other. The gendarmerie is made up of two sub-divisions, the socalled Great Commands (grands commandements): the territorial gendarmerie (gendarmerie territoriale) and the mobile gendarmerie (gendarmerie mobile). The territorial gendarmerie is the cornerstone of the gendarmerie and is responsible for national territory surveillance, gathering intelligence, and the execution of judiciary, military and administrative police missions. The mobile gendarmerie is specifically responsible for law enforcement all over the national territory, and for the protection of the authorities. It has absolutely no judiciary police missions and its members are therefore not judiciary police officers.

The second division relates to the territorial sharing of responsibilities between the National Police and the gendarmerie forces. Police units usually carry out their duties in urban areas and cities, whereas the gendarmerie intervenes in rural areas, and at borders (sometimes along with forest security and customs units).

Thirdly, there is a legal/functional division between the functions of the administrative and judiciary police, although this distinction is not always apparent, since police personnel can act in both functions. Indeed these two functions are exercised by both the National Police and the gendarmerie. Members of the two police organisations have, therefore, the status of both administrative and judiciary police. The administrative police are characterised as being, essentially, for preventive purposes, responsible for the protection of persons and property, and for law enforcement. Both the National Police and the national gendarmerie are in charge of responsibilities such as maintaining order, controlling and preventing crime, enforcing public peace, looking after public health, and regulating traffic. With particular regard to maintaining law and order, special units of the National Police (generally called 'Compagnie Républicaine de Sécurité' (CRS)) and the gendarmerie mobile (including, in most sensitive situations, the so-called 'Groupement d'Intervention de la Gendarmerie Nationale' (GIGN)) are mobilised. It is also important to note that with regard to law and order enforcement, there is a hierarchy between the different forces: the National Police are the first class of force who can maintain public order. The gendarmerie becomes involved as the second category force. Under exceptional circumstances (e.g. in a state of emergency), the armed forces may be called in as a third category force to back up the police and gendarmerie forces.

The judiciary police could be described as repressive; it is responsible for the detection and investigation of crime, and the arrest of suspects. The judiciary police units of the gendarmerie and the National Police are specifically trained to be responsible for discovering crimes, gathering evidence, and seeking out offenders. In both organisations the judiciary police are answerable to the Minister of Justice. When they act as judiciary police, the police and the gendarmerie forces come under the authority of the courts, particularly the juge d'instruction (examining magistrate) and the procureur (prosecutor). Furthermore, it is important to stress the fact that, in addition to their judiciary and law-enforcement duties, gendarmerie forces also have a military defence function (military police, gathering intelligence, protecting sensitive sites) and perform several more directly combat-related tasks in the event of war. Finally, both National Police and gendarmerie forces are increasingly taking part in international peacekeeping missions.

\subsubsection{Are the gendarmerie forces an anachronism $?^{2}$}

To a number of observers, the gendarmerie forces are seen as something of an anachronism, or anomaly, since they represent the continuation of a military presence in domestic security, and therefore legitimise the involvement of the armed forces in internal security matters. The existence of the gendarmerie has been accused of being a violation of the basic principle of the liberal-democratic state with the distinction between the police and the military. Due to their militarised status, the gendarmerie is sometimes associated with authoritarianism and repression tendencies. One of the core problems that are common to a number of Francophone African countries is the insufficient separation and blurred responsibilities between the police and the military forces. Militarised police forces such as the gendarmerie are consequently seen as making this tendency worse. Moreover, the difference that is defined between the police and the gendarmerie lies in their jurisdiction: cities as 
the police forces' jurisdictions versus the countryside as the gendarmerie forces' jurisdiction. Yet, in many francophone countries, this distinction is no longer respected.

Nevertheless, despite such critiques, the gendarmerie is often considered an elite corps: that is why its recruitment may be more stringent than for other services, such as the army or the National Police forces. Gendarmes generally enjoy a better reputation than the other security forces: they appear to be a disciplined corps respectful of hierarchy. The gendarmerie has generally experienced fewer mutinies than other security forces. More often than not they have not been involved in any forcible takeovers of power. However, the gendarmeries have been viewed as a central unit that protects the regime, and has sometimes been used as a tool of repression against opposition movements. In other countries, they are seen as a rival to the army.

A number of francophone countries have suppressed their gendarmerie forces, as with Belgium in Europe, or Burundi and the Democratic Republic of Congo in Africa. There is currently a debate in France, where a number of voices have been pleading for the suppression of the gendarmerie, in the context of budgetary restrictions that makes the dual police system unaffordable. Conversely, Switzerland decided to create a gendarmerie-type force in early 2000.

In contrast, it seems to a number of specialists that the intermediary, gendarmerie-type of security force is growing in significance (Lutterbeck 2004). According to them, the emergence of a growing number of transnational risks and threats that increasingly challenge the traditional distinction between internal and external security make the case for more agencies that are located between levels of internal and external security. The distinction between external security on the one hand - identified with mainly military threats coming from the aggressive behaviour of other states; and, on the other hand, internal security identified as criminal, or otherwise disturbing activities, within the boundaries of a state, are being increasingly blurred. This implies that both crime and war have tended to meet and, consequently, the role of the military and the police forces have increasingly coincided. In a number of aspects, such as with formal affiliation, internal structures and armoury, the gendarmeries occupy an intermediary position between internal and external security forces. The gendarmerie forces are organised along military lines and are thus more centralised and hierarchical than the civilian police forces. They are also equipped with heavier equipment than common police forces (armoured cars, light infantry weapons). Finally, as mentioned above, the gendarmeries have a double affiliation with the Ministry of Defence and the Ministry of Interior and carry out their judiciary police missions under the supervision of the Ministry of Justice.

Due to the fact that they combine both the characteristics of police and military forces, the gendarmeries are seen by some observers as particularly appropriate institutions to deal with challenges that emerge in Africa. They are seen as a relevant force that can easily be mobilised to deal with:

- border control to respond to various transnational challenges (fighting arms and drug trafficking). Gendarmerie forces are increasingly mobilised for border enforcement, sometimes along with the armed forces;

- peace operations, especially in the attempts at post-war reconstruction. African crises are often characterised by the gravity of the offences and crimes that have been committed, mostly against civilians, by troublemakers. Due to their double affiliation, gendarmerie forces can be deployed both under civilian (for law enforcement as well as judiciary missions) and under military command (their military skills enabling them to engage in fighting missions in cases of the deterioration of situations from post-conflict to war). It has also been suggested that the gendarmerie forces could act as judiciary auxiliaries to the International Penal Court.

Such views have inspired a new project: the Organisation des Gendarmeries Africaines (African Gendarmeries Organisation, OGA). A

Convention setting up the OGA was signed and adopted by a number of Francophone African countries which belong to three different areas in Francophone Africa: North (Maghreb, Mali and Niger); Western African countries (Senegal, Cote d'Ivoire, Togo, Benin, Burkina Faso, Guinea); and Eastern and Central Africa (Chad, RCA, Cameroon, Congo, Gabon, Djibouti and Madagascar). Senegal hosts the Secretariat of 
the OGA. On 20 June 2006, the French Minister of Interior officially announced that France was willing to support the setting up of an African gendarmerie force, similar to the European gendarmerie force, which was launched within the framework of the European Security and Defence Policy (ESDP) (Franceschi 2006, 2007).

Beyond Francophone Africa, the debate around the relevance of civilian police forces with military status may be of interest for Anglophone Africa.

\subsubsection{The municipal police}

The municipal police are generally controlled by the Ministry of Territorial Administration. Supervising municipal police services is one of the responsibilities of the municipalities. The municipal police, therefore, come under the authority of a mayor, and operate under a municipal police commandant. They are a police of proximity. Their attributions are to:

- ensure the safety and the convenience of public activities on streets, public highways, and other public facilities - notably cleaning, lighting, the removal of congestion, the demolition or repair of unsafe buildings; repress infringements on public order (fights, crowds, noise and night-gatherings);

- maintain order during large gatherings; inspect the accuracy of measures of foodstuff sold by weight or by measure and the healthiness of edible food on sale;

- ensure the protection of persons and of public and private goods;

- and guarantee the preservation of public places like waterways, forests, hunting and fishing services.

Municipal policemen have an obligation to report all occurrences falling under the jurisdiction of the National Police, and to give assistance to repress breaches of the peace, morality and neatness of the city.

In some francophone countries, municipal police forces operate alongside National Police forces based in towns. However, in many countries, municipal police forces only exist in theory.

\subsection{Organisation of the police forces in Anglophone Africa}

In Anglophone Africa, all the police forces are nationally controlled, i.e. they have a central command at the national level (Hills 2000, 2007). Most police forces are therefore territorially organised into national headquarters, provincial, divisional and district commands. However, the different specialised functions of policing also determine the organisation of the police. While the regular police enforce the law and work to prevent, detect and fight crime, paramilitary police concentrate on the preservation of public order. The paramilitary police, commonly known as Police Mobile Unit or Police Mobile Force, are present in many countries, including Botswana, Malawi, Nigeria (the Police Mobile Force), Mauritius, Malawi and Lesotho. Paramilitary police forces are known as the General Service Units in Kenya, the Police Intervention Unit in the Gambia, and the Rapid Response Unit in Uganda: personnel of these specialised police are drafted from the regular police and given special training. These mobile units can be compared to the CRS of the police forces and to the mobile units of the gendarmerie in francophone countries. In some cases, paramilitary police are deployed together with the military in internal operations during periods of disorder. In some countries, paramilitary police forces have access to hard military weapons, including helicopters, gunships and armoured personnel carriers. Paramilitary policing has therefore been the hallmark of policing in Anglophone Africa, particularly when it comes to dealing with serious internal crises.

There are no counterparts to the municipal police forces that can be found in a number of francophone countries. However, the practice of 'proximity policing' developed by the francophone municipal police may be interestingly compared to the practice of 'community policing' developed by anglophone police forces.

\section{Training capacities}

In Francophone Africa, of special interest is the concept of ENVR (Ecoles Nationales a Vocation Regionale - National Schools with Regional Vocation). The ENVR's aim is to adapt the training that is traditionally taught in French military schools to the particularities of the African continent. The ENVRs are supported by France and are meant to welcome trainees who come from all francophone countries. 25-50 per cent of the available positions are booked for trainees who originate from the host nation. Trainees have to pass an entrance examination to have access to the schools. Some of these 
schools are called upon to work closely with regional organisations, including the African Union (AU) and, in the long run, to become excellence training centres for the AU standby brigades. Currently, there are 14 ENVRs in Africa, located in 10 francophone countries: Benin, Burkina Faso, Mali, Niger, Senegal, Togo in West Africa, and Cameroon and Gabon in Central Africa. They offer 50 different types of training, which generally relate to three major areas: military general training; support of peace operations; and specialised training. A number of these training areas are bilingual

(French/English). The most recent ENVR is the so-called EIFORCES (International Security Forces Training School) in Awaé, Cameroon, meant to train both police and gendarmerie forces for peacekeeping-related missions.

The ENVR works with the same principles as the Kofi Annan Peacekeeping Centre in Accra and the National War College in Abuja.

\section{State of the art research on SSR}

An important amount of knowledge has been accumulated on the security sector in

Anglophone Africa, thanks to the expertise and research activities carried out by a lively network of research centres such as the African Security Sector Network, African Security Dialogue and Research, the Centre for Democracy and Development, the Southern African Defence and Security Management Network, and the Centre for Policy Research and Dialogue, based in Eastern, Western and Southern Africa.

In contrast, carrying out documentary research into institutional security development in Francophone Africa is a real challenge: there is little information and few materials - either as primary or secondary sources - available in the public domain. Only a few states have compiled the statutory rules of their civil service, and texts relating to the special statutes that characterise most of the defence and security forces in Francophone African states are unavailable. As a consequence, priority must be given to European or North American research or documentation centres when carrying out documentary research into the security sector of an African francophone country. In addition, there are no organised SSR-focused research capabilities of any importance that can be identified in Francophone Africa. Individual academics - rather than research centres, networks or think tanks - are working on SSR topics in an isolated way. It is important to note, however, that these people, if not numerous, do generally have a very deep knowledge of African francophone security systems. Often, they belong to research centres that are specialised in international relations, strategic studies or geopolitics (see for instance N'Diaye 2007; Agokla 2010; Sangaré 2006; Toulabor 2005; Bryden et al. 2008). A lot of francophone practitioners have also developed specialised skills in the field of security reform. If connected to a strong network, these academics and practitioners could make invaluable contributions to SSR in Francophone Africa.

It is important to acknowledge that difficulties in conducting research in most of Africa, and particularly Francophone Africa, constitutes in some cases a wilful obstacle to knowledge production for analysis and sound policy formulation: it is in itself a major hurdle to the improvement of security provision and stability. Furthermore, the 'secrets' that these practices are supposed to protect are often common knowledge.

\section{Conclusion}

The time is ripe to share and build upon the experience of both Francophone and Anglophone (and Lusophone) Africa within shared policy frameworks/concerns, either by extending the theory and practice of SSR to francophone countries, or through other less intrusive forms of experience-sharing. Yet institutional variations matter and have to be understood and built into policy and practice on SSR. The general principles of SSR are no doubt relevant to Francophone Africa as well. However, for SSR programmes to be efficient in Francophone Africa there is a need to recognise that, beyond sharing a common language, the majority of Francophone African states share a specific model from an institutional, organisational and procedural standpoint. Today, the major international actors involved in SSR acknowledge that the peculiarities of French-speaking African environments have not been sufficiently taken into account in the original conceptualisation of SSR as well as the implementation of policies on the ground. A thorough knowledge of these features is consequently necessary to ensure the success of reforms in Francophone Africa, both in post-conflict environments and conflict prevention strategies. 


\section{Notes}

1 Former Belgian colonies are not reviewed here.

\section{References}

Agokla, K. (2010) 'Le Cadre Institutionnel et le Système de Sécurité au Togo', in K. Agokla, N. Bagayoko and B. N'Diaye (eds), La Réforme des Système de Sécurité et de Justice en Afrique Francophone, Paris: Organisation internationale de la Francophonie (OIF)

Anderson, D.M. and Killingray, D. (1992) Policing and Decolonisation: Nationalism, Politics and the Police, 1917-1965, Manchester: Manchester University Press

Bayley, D.H. (1985) Patterns of Policing: A Comparative International Analysis, New Brunswick, New Jersey: Rutgers University Press

Bryden A.; N'Diaye, B. and Olonisakin, F. (dir. publ.) (2008) Gouvernance du Secteur de la Sécurité en Afrique de l'Ouest: Les Défis à Relever, Zürich and Berlin: Lit Verlag

Franceschi, P. (2007) 'Plaidoyer pour la Création de Forces de Gendarmeries Africaines', Défense Nationale et Sécurité Collective 10: 179-86

Franceschi, P. (2006) 'La Régionalisation du Maintien de la Paix en Afrique: Une Evolution des Rapports entre les Gendarmeries Africaines', Revue de la Gendarmerie Nationale 220

Hills, A. (2007) 'Police Commissioners, Presidents and the Governance of Security', Journal of Modern African Studies 45.3
2 This title refers to the analysis of Bayley (1985) who viewed the persistence of the gendarmerie as somewhat of an anachronism.

Hills, A. (2000) Policing Africa: Internal Security and the Limits of Liberalisation, Boulder CO: Lynne Rienner

Kurian, G.T. (2006) World Encyclopaedia of Police Forces and Correctional Systems, 2nd edn, Detroit: Thomson Gale

Lutterbeck, D. (2004) 'Between Police and Military: The New Security Agenda and the Rise of Gendarmeries', Cooperation and Conflict: Journal of Nordic International Studies Association 39.1

N'Diaye B. (2007) 'Security "A la Française": Francophone Africa's Security Sector NonTransformation', draft paper

Sangaré, N. (2006) 'Mali', in E. Hutchful and W. Omitoogun (eds), Budgeting for the Military Sector in Africa: The Processes and Mechanisms of Control, New York: SIPRI (Stockholm International Peace Research Institute), Oxford University Press

Toulabor, C. (2005) Les Forces Armées Togolaises et le Dispositif Sécuritaire de Contrôle (1\&2), Articles sur la Toile à l'adresse, www.ufctogo.com/Lesforcesarmees-togolaises-et-le-1082.html (accessed 8 March 2010) 